\title{
FAKTOR-FAKTOR YANG MEMPENGARUHI AUDIT DELAY PADA PEMERINTAH KABUPATEN/KOTA DI INDONESIA
}

\section{FACTORS AFFECTING DELAY AUDITS IN DISTRICT/ CITY GOVERNMENT IN INDONESIA}

\author{
Zaenal Wafa ${ }^{1}$, Nugraeni ${ }^{2}$ \\ ${ }^{12}$ Prodi Akuntansi FE Universitas Mercu Buana Yogyakarta \\ 2nda_eni@yahoo.com
}

\begin{abstract}
Abstrak
Pemerintah daerah berkewajiban untuk memastikan bahwa laporan keuangan mereka disajikan secara tepat waktu karena laporan keuangan tersebut merupakan bentuk pertanggungjawaban kepada publik. Laporan keuangan tersebut dapat digunakan oleh publik untuk mengevaluasi kapabilitas pemerintah daerah dalam mengelola sumberdaya yang dimiliki secara efektif dan efisien. Ketepatan waktu laporan keuangan berperan penting dalam rangka pengambilan keputusan pemerintah. Berdasarkan Undang-Undang (UU) Nomor 17 tahun 2003 tentang Keuangan Negara, bahwa waktu penyampaian laporan keuangan pemerintah daerah kepada DPRD adalah 6 (enam) bulan setelah tahun anggaran berakhir (Pasal 31 ayat 1). Untuk memenuhi ketepatan waktu laporan keuangan, Pemerintah Daerah dan auditor diharapkan dapat meminimalkan audit delay. Audit delay merujuk pada perbedaan waktu antara tanggal laporan keuangan dengan tanggal opini audit dalam laporan keuangan (Subekti dan Widiyanti, 2004). Tujuan penelitian ini untuk menganalisis faktor-faktor yang dapat mempengaruhi audit delay pada pemerintah kabupaten/kota. Faktor-faktor tersebut yaitu ukuran pemerintah daerah, pengalaman pemerintah daerah dalam menerapkan Standar Akuntansi Pemerintah (SAP), jumlah temuan audit, dan opini audit yang diberikan oleh BPK RI atas laporan keuangan pemerintah daerah. Populasi penelitian seluruh pemerintah daerah Kabupaten/Kota di Indonesia. Analisis data menggunakan regresi berganda. Hasilnya semua variabel berpengaruh terhadap audit delay baik secara parsial maupun simultan. Besar pengaruh semua variabel sebesar 70,9\% sedang sebesar $29,1 \%$ dipengaruhi oleh variabel lain
\end{abstract}

Kata Kunci : audit delay, ukuran pemerintah daerah, pengalaman menerapkan SAP, jumlah temuan audit, dan opini audit

\begin{abstract}
Local governments are obliged to ensure that their financial statements are presented in a timely manner as they are a form of accountability to the public. These financial reports can be used by the public to evaluate the capabilities of local governments in managing their resources effectively and efficiently. Timeliness of financial statements plays an important role in the framework of government decision making. Based on Law No. 17 of 2003 on State Finances, the submission time of local government financial statements to Regional House of Representatives is 6 (six) months after the fiscal year ends (Article 31 paragraph 1). To meet the timeliness of financial statements, Local Government and auditors are expected to minimize the audit delay. The delay audit refers to the time difference between the date of the financial statements and the date of audit opinion in the financial statements (Subekti and Widiyanti, 2004). The purpose of this study is to analyze the factors that may affect audit delay at the district / city government. These factors are the size of local government, the experience of local governments in applying the Government Accounting Standards, the number of audit findings, and the audit opinion provided by the Indonesian Supreme Audit Institution on local government financial reports. The study population was all local government districts/cities in Indonesia. Analysis of data used multiple regression. The
\end{abstract}


results show all variables affect the audit delay either partially or simultaneously. The influence of all variables is $70.9 \%$ while $29.1 \%$ is influenced by other variables.

Keywords: audit delay, size of local government, experience of implementing SAP, audit findings, and audit opinion

\section{PENDAHULUAN}

Pemerintah daerah berkewajiban untuk memastikan bahwa laporan keuangan mereka disajikan secara tepat waktu karena laporan keuangan tersebut merupakan bentuk pertanggungjawaban kepada publik, Mohamad (2012). Laporan keuangan tersebut dapat digunakan oleh publik untuk mengevaluasi kapabilitas pemerintah daerah dalam mengelola sumberdaya yang dimiliki secara efektif dan efisien. Pada sektor pemerintah, ketepatan waktu laporan keuangan berperan penting dalam rangka pengambilan keputusan pemerintah. Berdasarkan Undang-Undang (UU) Nomor 17 tahun 2003 tentang Keuangan Negara, bahwa waktu penyampaian laporan keuangan pemerintah daerah kepada DPRD adalah 6 (enam) bulan setelah tahun anggaran berakhir (Pasal 31 ayat 1).

Berdasarkan Ikhtisar Hasil Pemeriksaan Semesteran (IHPS) semester II Badan Pemeriksa Keuangan (BPK) pada tahun 2012, 2013 dan 2014 diketahui pada tahun 2012 terdapat $92(18,5 \%)$ pemerintah kabupaten/kota yang terlambat menyampaikan laporan keuangannya. Pada tahun 2013 jumlahnya 62 (12,98\%) pemerintah kabupaten/kota dan pada tahun 2014 sebanyak 35 (6,49\%) pemerintah kabupaten/kota laporan keuangannya terlambat.

Untuk memenuhi ketepatan waktu laporan keuangan, manajer dan auditor diharapkan dapat meminimalkan audit delay. Audit delay merujuk pada perbedaan waktu antara tanggal laporan keuangan dengan tanggal opini audit dalam laporan keuangan (Subekti dan Widiyanti, 2004). Menurut Cohen dan Leventis (2012), audit delay pada pemerintah kota dipengaruhi oleh beberapa faktor yaitu faktor politik, yaitu kekuatan oposisi dan keterpilihan kembali kepala daerah, keberadaan tim akuntansi internal, jumlah temuan audit, ukuran pemerintah daerah dan populasi penduduk.

Pemerintah daerah yang memiliki ukuran besar kecenderungan untuk memiliki transaksi keuangan yang lebih banyak dibandingkan pemerintah daerah yang berukuran kecil. Banyaknya transaksi keuangan akan menyebabkan pengelolaan keuangan bertambah rumit sehingga penyusunan laporan keuangan akan membutuhkan waktu yang lebih lama. Hal tersebut akan menyebabkan penyampaian laporan keuangan kepada auditor menjadi lebih lama dan akan menambah audit delay.

Pengalaman pemerintah daerah dalam menerapkan SAP dapat mengurangi audit delay. Pengalaman pemerintah daerah dalam menerapkan SAP dapat diartikan sebagai pengalaman pegawai pemerintah daerah dalam menyusun laporan keuangan. Dengan pengalamannya, pegawai pemerintah daerah akan menjadi mahir dalam menyusun laporan keuangan sehingga waktu untuk menyusun laporan keuangan akan menjadi lebih cepat dan audit delay dapat berkurang.

Temuan audit merupakan penyimpangan-penyimpangan yang dilakukan oleh pemerintah daerah atas standar dan atau peraturan yang terkait dengan pengelolaan keuangan daerah. Sebelum ditetapkan dalam Laporan Hasil Pemeriksaan (LHP) BPK, temuan audit akan dikomunikasikan kepada pemerintah daerah yang bersangkutan untuk memperoleh tanggapan/klarifikasi atas temuan tersebut. Jumlah temuan audit yang banyak akan menambah waktu pemerintah daerah dalam memberikan tanggapan sehingga penyelesaian laporan audit menjadi lebih lama dan audit delay akan bertambah.

Opini Wajar Tanpa Pengecualian (WTP) merupakan capaian tertinggi dalam penerapan standar akuntansi dan pengelolaan keuangan. Mendapatkan opini WTP dari 
BPK atas laporan keuangan pemerintah daerah merupakan salah satu cita-cita kepala daerah di seluruh Indonesia. Mendapatkan opini WTP adalah sebuah prestasi bagi seorang kepala daerah. Opini WTP merupakan kabar gembira bagi pemerintah daerah sehingga selayaknya untuk disampaikan sesegera mungkin kepada masyarakat. Opini audit selain opini WTP dapat diartikan sebagai kabar buruk bagi pemerintah daerah dan tidak selayaknya untuk dismapaikan sesegera mungkin sehingga LHP BPK menjadi terlambat. Sehingga dapat diartikan opini audit selain opini WTP akan menambah audit delay.

\section{Ukuran Pemerintah Daerah dan audit delay}

Apabila diinterpretasikan dengan faktor-faktor yang mempengaruhi lamanya waktu penyelesaian audit pada perusahaan manufaktur, terdapat faktor yang mempengaruhi lamanya waktu penyelesaian audit salah satunya yaitu ukuran perusahaan. Ukuran perusahaan ini dapat dilihat dari beberapa proksi diantaranya total aset dan total pendapatan. Hal ini dapat dihubungkan dengan instansi pemerintah. Ukuran pemerintah dapat dilihat dari jumlah APBD. Semakin besar APBD maka dapat diasumsikan bahwa semakin besar pula pemerintah tersebut. Menurut Payne dan Jensen (2002), ukuran kota yang besar akan mengalami audit delay yang lebih lama. Hal ini terkait dengan meningkatnya jumlah transaksi keuangan pada kota tersebut. Apabila dikaitkan dengan ukuran pemerintah, maka pemerintah daerah dengan APBD besar akan menyebabkan audit delay semakin lama.

Maka hipotesis yang diajukan adalah:

H1 : ukuran pemerintah daerah berpengaruh terhadap audit delay pada pemerintah daerah kabupaten/kota di Indonesia

\section{Pengalaman Pemerintah Menerapkan SAP dan audit delay}

Pengalaman pemerintah dalam menerbitkan laporan keuangan akan memberikan efek positif terhadap kepatuhan pemerintah terhadap SAP (Ryan, Stanley dan Nelson, 2002). Menurut Owusu-Ansah (2002), organisasi (pemerintah) yang terus menerapkan SAP, menyebabkan pegawai pemerintah daerah (akuntan internal) belajar lebih banyak mengenai masalah yang menyebabkan lamanya audit delay. Sedangkan Christiaens dan Peteghem (2007) menjelaskan pemerintah yang sudah berpengalaman banyak dalam menerbitkan laporan keuangan akan menjadi ahli dalam menangani masalah laporan keuangan.

Maka hipotesis yang diajukan adalah:

$\mathrm{H} 2$ : pengalaman pemerintah menerapkan SAP berpengaruh terhadap audit delay pada pemerintah daerah kabupaten/kota di Indonesia

\section{Jumlah temuan audit dan audit delay}

Hasil audit atas laporan keuangan pemerintah daerah oleh BPK berupa opini dan temuan audit. Temuan audit adalah permasalahan-permasalahan yang ditemukan oleh auditor dilapangan. Jumlah temuan audit berpengaruh pada lamanya penyelesaian laporan audit. Menuurt Cohen dan Leventis (2013) komunikasi antara auditan dengan auditor menjadi lebih intens dan menjadi lebih lama ketika terdapat permasalahan akuntansi. Permasalahan akuntansi yang dimaksud adalah temuan audit yang material. Banyaknya temuan audit akan menambah waktu diskusi temuan baik di internal BPK antara tim audit lapangan dengan penanggungjawab audit maupun diskusi temuan dengan pemerintah daerah selaku auditan sebelum temuan tersebut layak untuk diangkat dalam laporan hasil audit. Selain itu, banyaknya temuan audit akan menambah waktu bagi auditan dalam memberikan tanggapan atas temuan tersebut.

Maka hipotesis yang diajukan adalah: 
H3 : jumlah temuan audit berpengaruh terhadap audit delay pada pemerintah daerah kabupaten/kota di Indonesia

\section{Opini audit dan audit delay}

Selain temuan audit, hasil audit BPK atas laporan keuangan adalah opini atas laporan keuangan pemerintah daerah. Opini BPK atas laporan keuangan pemerintah ada empat jenis yaitu: Wajar Tanpa Pengecualian (WTP), Wajar Dengan Pengecualian (WDP), Tidak Wajar (TW) dan Tidak Memberikan Pendapat (TMP). Menurut McLelland dan Giroux (2000) opini WTP (unqualified opinion) merupakan sebuah kabar bagus yang harus dilaporkan sesegera mungkin. Berdasarkan pendapat tersebut dapat dianalogikan bahwa opini selain opini WTP (yaitu opini WDP, TW dan TMP) adalah sebuah kabar buruk yang sebaiknya tidak dilaporkan. Selain itu, menuurt Payne dna Jensen (2002) opini WDP mengindikasikan adanya tambahan prosedur yang dibutuhkan selama pelaksanaan audit yang akan meningkatkan audit delay.

Maka hipotesis yang diajukan adalah:

$\mathrm{H} 4$ : opini audit berpengaruh terhadap audit delay pada pemerintah daerah

kabupaten/kota di Indonesia

\section{METODE}

\section{Pengumpulan data dan pengambilan sampel}

Populasi dalam penelitian ini adalah laporan keuangan pemerintah daerah kabupaten/kota di Indonesia tahun 2015 atau hasil audit BPK tahun 2016. Pengambilan sampel dengan metode purposiv sampling dengan kriteria sbb:

1. Bukan daerah pemekaran

2. Pencatatan akuntansi menggunakan basis akrual

3. Datanya lengkap

Dari 516 kabupaten/kota yang diaudit oleh BPK, yang memenuhi kriteria sehingga bisa diolah selanjutnya adalah 240 kabupaten/kota.

\section{Definisi Operasional variabel}

Audit delay (AD), yaitu lamanya penyelesaian audit yang diukur dari tanggal akhir tahun anggaran hingga tanggal diterbitkannya laporan audit oleh auditor. Pengukurannya dilakukan secara kuanatitatif dari tanggal berakhirnya tahun buku pemerintah daerah (31 Desember) hingga tanggal diterbitkannya laporan audit oleh BPK. Ukuran pemerintah daerah (LogAPBD/X1), dinyatakan dengan ukuran kuantitatif yaitu total realisasi pendapatan yang tercantum dalam laporan realisasi anggaran pemerintah daerah pada tahun bersangkutan kemudian ditransformasi ke logaritma 10. Pengalaman menerapkan SAP (Pengalaman/X2), dinyatakan secara kuantitatif jumlah tahun pemerintah daerah menerbitkan laporan keuangan yang diukur dari tahun diberlakukannya Standar Akuntansi Pemerintah tahun 2010 sampai dengan tahun sampel penelitian. Jumlah temuan audit (Temuan/X3), diukur secara kuantitatif jumlah temuan audit yang tercantum dalam laporan hasil pemeriksaan atas laporan keuangan daerah tahun anggaran bersangkutan oleh BPK. Opini audit (Opini/X4), berupa jenis opini yang diberikan oleh BPK terhadap laporan keuangan pemerintah daerah yang tercantum dalam LHP BPK. Apabila opini BPK adalah WTP diberi kode (0), sedangkan apabila opini WDP diberi kode (1), opini TW diberi kode (2) dan opini TMP diberi kode (3).

\section{Tekik analisis data}

Hipotesis dalam penelitian ini diuji menggunakan analisis regresi berganda (multiple regression) dengan persamaan: 


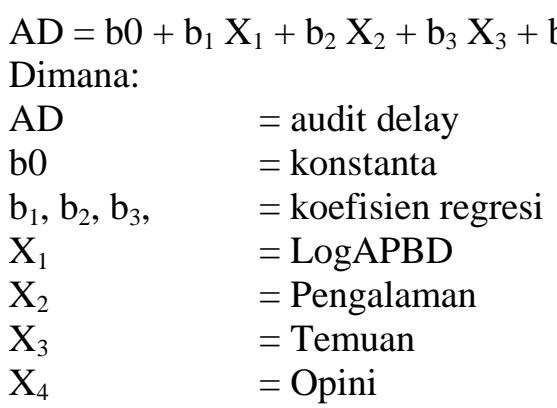

\section{HASIL DAN PEMBAHASAN}

Hipotesis 1 adalah pengujian untuk melihat pengaruh ukuran pemerintah daerah terhadap audit delay pada pemerintah daerah kabupaten/kota di Indonesia. Dari tabel 1 terlihat bahwa $\mathrm{t}$ hitung $(2,352)>\mathrm{t}$ tabel $(1,972)$ atau nilai signifikansi $0,026<0,05$, hal ini menandakan bahwa hipotesis 2 yang menyatakan bahwa ukuran pemerintah daerah berpengaruh terhadap audit delay pada pemerintah daerah kabupaten/kota di Indonesia diterima. Menurut Payne dan Jensen (2002), ukuran kota yang besar akan mengalami audit delay yang lebih lama. Hal ini terkait dengan meningkatnya jumlah transaksi keuangan pada kota tersebut. Apabila dikaitkan dengan ukuran pemerintah, maka pemerintah daerah dengan APBD besar akan menyebabkan audit delay semakin lama.

Hipotesis 2 adalah pengujian untuk melihat pengaruh pengalaman pemerintah menerapkan SAP terhadap audit delay pada pemerintah daerah kabupaten/kota di Indonesia. Dari tabel 5.7 terlihat bahwa t hitung $(2,865)>\mathrm{t}$ tabel $(1,972)$ atau nilai signifikansi $0,038<0,05$, hal ini menandakan bahwa hipotesis 3 yang menyatakan bahwa pengalaman pemerintah menerapkan SAP berpengaruh terhadap audit delay pada pemerintah daerah kabupaten/kota di Indonesia diterima. Pengalaman pemerintah dalam menerbitkan laporan keuangan akan memberikan efek positif terhadap kepatuhan pemerintah terhadap SAP (Ryan, Stanley dan Nelson, 2002). Menurut Owusu-Ansah (2002), organisasi (pemerintah) yang terus menerapkan SAP, menyebabkan pegawai pemerintah daerah (akuntan internal) belajar lebih banyak mengenai masalah yang menyebabkan lamanya audit delay. Sedangkan Christiaens dan Peteghem (2007) menjelaskan pemerintah yang sudah berpengalaman banyak dalam menerbitkan laporan keuangan akan menjadi ahli dalam menangani masalah laporan keuangan.

Hipotesis 3 adalah pengujian untuk melihat pengaruh jumlah temuan audit terhadap audit delay pada pemerintah daerah kabupaten/kota di Indonesia. Dari tabel 5.7 terlihat bahwa $\mathrm{t}$ hitung $(23,286)>\mathrm{t}$ tabel $(1,972)$ atau nilai signifikansi $0,000<0,05$, hal ini menandakan bahwa hipotesis 6 yang menyatakan bahwa jumlah temuan audit berpengaruh terhadap audit delay pada pemerintah daerah kabupaten/kota di Indonesia diterima. Temuan audit adalah permasalahan-permasalahan yang ditemukan oleh auditor dilapangan. Jumlah temuan audit berpengaruh pada lamanya penyelesaian laporan audit. Menuurt Cohen dan Leventis (2013) komunikasi antara auditan dengan auditor menjadi lebih intens dan menjadi lebih lama ketika terdapat permasalahan akuntansi. Permasalahan akuntansi yang dimaksud adalah temuan audit yang material. Banyaknya temuan audit akan menambah waktu diskusi temuan baik di internal BPK antara tim audit lapangan dengan penanggungjawab audit maupun diskusi temuan dengan pemerintah daerah selaku auditan sebelum temuan tersebut layak untuk diangkat dalam laporan hasil audit. Selain itu, banyaknya temuan audit akan menambah waktu bagi auditan dalam memberikan tanggapan atas temuan tersebut.

Hipotesis 4 adalah pengujian untuk melihat pengaruh opini audit terhadap audit delay pada pemerintah daerah kabupaten/kota di Indonesia. Dari tabel 5.7 terlihat bahwa $\mathrm{t}$ 
hitung $(-10,644)>t$ tabel $(1,972)$ atau nilai signifikansi $0,000<0,05$, hal ini menandakan bahwa hipotesis 4 yang menyatakan bahwa opini audit berpengaruh terhadap audit delay pada pemerintah daerah kabupaten/kota di Indonesia diterima. Selain temuan audit, hasil audit BPK atas laporan keuangan adalah opini atas laporan keuangan pemerintah daerah. Opini BPK atas laporan keuangan pemerintah ada empat jenis yaitu: Wajar Tanpa Pengecualian (WTP), Wajar Dengan Pengecualian (WDP), Tidak Wajar (TW) dan Tidak Memberikan Pendapat (TMP). Menurut McLelland dan Giroux (2000) opini WTP (unqualified opinion) merupakan sebuah kabar bagus yang harus dilaporkan sesegera mungkin. Berdasarkan pendapat tersebut dapat dianalogikan bahwa opini selain opini WTP (yaitu opini WDP, TW dan TMP) adalah sebuah kabar buruk yang sebaiknya tidak dilaporkan. Selain itu, menurut Payne dna Jensen (2002) opini WDP mengindikasikan adanya tambahan prosedur yang dibutuhkan selama pelaksanaan audit yang akan meningkatkan audit delay.

Tabel 1. Coefficients ${ }^{\mathrm{a}}$

\begin{tabular}{|c|c|c|c|c|c|c|c|c|}
\hline & Model & $\begin{array}{l}\text { Unstan } \\
\text { Coeff }\end{array}$ & $\begin{array}{l}\text { rdized } \\
\text { ients }\end{array}$ & $\begin{array}{l}\text { Standardized } \\
\text { Coefficients }\end{array}$ & $\mathbf{t}$ & Sig. & $\begin{array}{l}\text { Collinea } \\
\text { Statist }\end{array}$ & \\
\hline & & B & Error & Beta & & & Tolerance & VIF \\
\hline 1 & (Constant) & 105,966 & 86,513 & & 1,225 & ,222 & & \\
\hline & Ukuran & 15,447 & 6,583 & ,023 & 2,352 & ,026 & ,630 & 1,588 \\
\hline & Pemda & & & & & & & \\
\hline & SAP & $-2,958$ & 1,032 &,- 030 & $-2,865$ & ,038 & ,990 & 1,010 \\
\hline & Temuan & 11,877 & ,510 & 1,053 & 23,286 & , 000 & ,596 & 1,679 \\
\hline & Opini & $-23,429$ & 2,201 &,- 479 & $10,644^{-}$ & ,000 & ,602 & 1,661 \\
\hline
\end{tabular}

a. Dependent Variable: Audit Delay

Sedang pengaruh keempat variabel yaitu ukuran pemerintah, pengalaman pemerintah menerapkan SAP, jumlah temuan audit dan opini audit secara bersama-sama terhadap audit delay dapat ditunjukan dalam tabel 2 dibawah ini. Dari tabel 2 dapat dilihat bahwa nilai signifikansi $<$ alfa, atau $0,000<0,05$. Hal ini menunjukan bahwa keempat variabel (ukuran pemerintah, pengalaman pemerintah menerapkan SAP, jumlah temuan audit dan opini audit) secara bersama-sama berpengaruh terhadap audit delay.

Tabel 2. ANOVA ${ }^{b}$

\begin{tabular}{llccccc}
\hline & Model & $\begin{array}{c}\text { Sum of } \\
\text { Squares }\end{array}$ & df & Mean Square & F & Sig. \\
\hline 1 & Regression & 165279,595 & 7 & 23611,371 & 84,181 &, $000^{\mathrm{a}}$ \\
& Residual & 65072,138 & 232 & 280,483 & & \\
& Total & 230351,733 & 239 & & & \\
\hline
\end{tabular}

a. Predictors: (Constant), Opini, SAP, Ukuran Pemda, Temuan

b. Dependent Variable: Audit Delay

\section{KESIMPULAN DAN SARAN}

Kesimpulan

1. Ukuran pemerintah daerah berpengaruh terhadap audit delay pada pemerintah daerah kabupaten/kota di Indonesia

2. Pengalaman pemerintah menerapkan SAP berpengaruh terhadap audit delay pada pemerintah daerah kabupaten/kota di Indonesia 
3. Jumlah temuan audit berpengaruh terhadap audit delay pada pemerintah daerah kabupaten/kota di Indonesia

4. Opini audit berpengaruh terhadap audit delay pada pemerintah daerah kabupaten/kota di Indonesia

5. Ukuran pemerintah daerah, Pengalaman pemerintah menerapkan SAP, Jumlah temuan audit dan Opini audit berpengaruh terhadap audit delay pada pemerintah daerah kabupaten/kota di Indonesia

\section{Saran}

Penelitian yang menggunakan data laporan keuangan pemerintah daerah kabupaten/kota hasil auditan dari BPK harus sabar, karena BPK baru menerbitkan laporan auditan dua tahun berikutnya. Seperti dalam penelitian ini laporan keuangan tahun 2015 baru selesai diaudit semua oleh BPK bulan Mei 2017.

\section{DAFTAR PUSTAKA}

Arens, A.A., R.J., Beasley, MS, 2011,"Auditing dan Pelayanan Verifikasi: Pendekatan Terpadu", alih bahasa oleh Tim Dejakarta, edisi kesembilan, Jakarta: Indeks.

Aryati, Titik dan Maria Theresia, 2005," Faktor-Faktor yang Mempengaruhi Audit Delay dan Timeliness," Media Riset Akuntansi, Auditing dan Informasi 5(3): 271-287.

Bastian, I, 2001, "Akuntansi Sektor Publik di Indonesia", Pusat Pengembangan Akuntansi, Yogyakarta, BPFE.

Carslaw, C.A.P.N., dan S.E. Kaplan, 1991, “An Examination of Audit Delay: Further Evidence From New Zealand”, Accounting and Business Research, Vol. 22 No. 85, Pp 21-32.

Chairiri, Anis dan Imam Ghozali, 2007; “Teori Akuntansi”, Fakultas Ekonomi: Universitas Diponegoro, Semarang.

Duwi Priyatno, 2009,"Belajar Olah data dengan SPSS 17”, Penerbit Andi Yogyakarta.

Leventis. S., dan Weetman, P, 2004, “Timeliness of Financial Reporting., Applicability of Disclosure Theory in an Eemrging Capital Market, Accounting and Business Research, Vol. 34, No. 1

Mardiasmo, 2009,"Akuntansi Sektor Publik", Yogyakarta Penerbit Andi.

McLelland, A.J. and Giroux,G. (2000)," An Empirical Analysis of Auditor Report Timing by Large Municipalities", Journal of Accounting and Public Policy, 19 (3): 263-281.

Owusu,-Ansah, S. (2000)," Timeliness of Corporate Financial Reporting in Emerging Capital Market: Empirical Evidence from the Zimbabwe Stock Exchange", Accounting and Business Research, 30: 241-254.

Payne, J. and Jensen, K.(2002)," An Examination of Municipal Audit Delay", Journal of Accounting and Public Policy, 21: 1-29. 
Permendagri No. 13 tahun 2006 tentang Pedoman Pengelolaan Keuangan Daerah.

PP No. 71 tahun 2010 : Standar Akuntansi Pemerintah berbasi akrual.

Ryan, Christine M. and Stanley, Trevor A. and Nelson, Morton , 2002," Accountability Disclosures by Queensland Local Government Councils 1997-1999”, Financial Accountability \& Management 18(3):pp. 261-289.

Scott, R.W, 2008," Institutions and Organizations: Ideas an Interest”, Los Angeles, London, New Delhi, Singapore: Sage Publication. Third Edition.

Subekti, Imam dan Widiyanti, 2004" Faktor-faktor yang berpengaruh terhadap audit delay di Indonesia”, Simopsium Nasional Akuntansi VII, Vali: 991-1002.

Sugiyono, 2010, Metode Penelitian Pendidikan: Pendekatan Kuantitatif, Kualitatif dan HRD, Bandung: Alfabeta.

2013, Metode Penelitian Kuantitatif, Kualitatif, dan R\&D, Bandung:Alfabeta.

Syahyuti, 2003," Bedah Konsep Kelembagaan : Strategi Pengembangan dan Penerapannya dalam Penelitian Pertanian”, Pusat Penelitian dan Pengembangan Sosial Ekonomi Pertanian. Bogor.

UU No. 32 Tahun 2004 : Pemerintahan Daerah.

UU No. 33 Tahun 2004 : Perimbangan Keuangan antara Pemerintah Pusat dan Pemerintahan Daerah. 